3. Вихованець I. Р. Теоретична морфологія української мови: Академ. граматика укр. мови. К.: Унів. вид-во «Пульсари», 2004. 400 с.

4. Граматика сучасної української літературної мови. Морфологія / За ред. К. Г. Городенської. К.: Видавничий дім Дмитра Бураго, 2017. $752 \mathrm{c}$.

5. Чеснокова Л. Д. Категория неопределленного множества и семантические формы мысли // Семантика грамматических форм / Отв. Ред. П. В. Чесноков. Ростов-на-Дону: Изд-во Ростовск. пед. ин-та, 1982. C. 21-31.

6. Словник буковинських говірок / За заг. ред. Н. В. Гуйванюк. Чернівці: Рута, 2005. 688 с.

DOI https://doi.org/10.30525/978-9934-26-073-5-1-13

\title{
МОДЕЛЮВАННЯ ФРЕЙМУ ДИКТАТОР НА МАТЕРІАЛІ ОПОВІДАННЯ ОЛЬГИ ТОКАРЧУК «КАЛЕНДАР ЛЮДСЬКИХ СВЯТ»
}

\section{Рогальська-Якубова I. I.}

кандидат філологічних наук, стариий викладач кафедри лінгвістичних підготовки Державного університету інтелектуальних технологій та зв 'язку м. Одеса, Украӥна

Фреймовий аналіз $є$ одним 3 популярних методів когнітивної лінгвістики. I хоча засновник теорії фреймів М. Мінський фреймом називав модель стереотипної ситуації, зараз за допомогою методу моделюються також статичні фрейми, фрейми почуттів тощо. Термін використовується для опису типової структури, призначеної організувати певну інформацію. У залежності від змісту впорядковуваної інформації виокремлюються слоти, термінали фрейму. Кількість слотів відповідає кількості елементів, що виділяються в даному фрагменті досвіду, слот має ім'я, яке задає сам параметр, і заповнюється інформацією про значення, що даний параметр приймає у даного типу об'єктів або даного конкретного екземпляра [4, с. 65].

Дослідники виділяють різні слоти фреймів. Наприклад, С.А. Жаботинська пропонує таку фреймову структуру: ЩОСЬ / ХТОСЬ - предмет, ТАКИЙ - якість, ІСНУЄ ТАК - буття, ТУТ / ТАМ - місце, ЗАРАЗ / ТОДІ - час [3, с. 11-12] - об'єктивовану в категоріях частин мови. 
Н.Ю. Шнякіна, досліджуючи перцептивні ситуації, виокремлює такі основні слоти, як суб'єкт, об'єкт, пізнавальна дія, інструмент, результат, простір, час [8, с. 216]. На думку Л.О. Бушуєвої, фрейми вчинків мають такий набір слотів: мотив/ мета, дія, агент, об'єкт, оцінка, результат [2, с. 3]. Іноді для моделювання фреймової структури використовують методику постановки спеціальних питань (Хто? Де? Коли? Як? Чому? В якому темпі розгортається дія? тощо) [1, с. 4]. Можна простежити певну подібність між ключовими слотами: завжди актуальними $\epsilon$ суб'єкт, дія, простір, час. Інші параметри актуалізуються в разі потреби для представлення того чи іншого фрагмента знань.

Метою нашого дослідження було моделювання фрейму диктатор за одним з бізарних (дивацьких) оповідань польської письменниці, лауреатки Нобелівської премії, Ольги Токарчук «Календар людських свят». Можна вичленувати кілька основних слотів 3 узуальною інформацією. За словником української мови, диктатор - особа, що має в державі необмежену владу [7, с. 275], за польськими словниками це «osoba mająca absolutną władzę w państwie» [9], «przywódca utrzymujący się przy władzy dzięki przemocy i terrorowi» [11]. Отже, ключові слоти тут: суб'єкт (сам диктатор), кількість (завжди один у країні), дія (керує державою), якість дії (одноосібне керування за допомогою насилля й терору), місце (будь-яка країна).

Інші слоти заповнюються другорядною, варіативною інформацією за матеріалами оповідання, де все подається крізь призму свідомості головного героя Ілона - масажиста диктатора Монодікоса. Ім'я Монодікос складається з двох грецьких слів: моно означає один (вказівка на кількість) і дікос - присвійний займенник, що використовується в разі відсутності іменника (у слов'янських мовах відсутній). Слот суб'єкт заповнюється термінальною інформацією про стан 312-річного диктатора. Зараз це просто тіло в рубцях і шрамах: „Niektóre miejsca... były jedna nigdy do końca niezagojona blizną» [10, c. 206]. П'ять років тому праву частину тіла паралізувало: „,mózg ulegt uszkodzeniu, bardzo poważnemu, a po wszystkim pojawit się paraliż prawej strony tacznie $z$ twarzą [10, c. 210]. Уже 25 років Монодікос не чув і не розмовляв: „Monodikos jest niemal gtuchy od czasu, gdy 25 lat temu zostat potężnie uderzony w głowę. Cała kość skroniowa popękała, a jej kawatki uszkodzity mózg... Od tamtej pory Monodikos nie mówit» [10, c. 219]. Перелік хвороб й ушкоджень безкінечний: „pęknięty mięsień dwugtowy, zerwane ścięgno Achillesa, połamane kości śródręcza lewej dłoni, wywichnięcie stawu skokowego, zmiażdżona rzepka kolanowa, uszkodzenie trzustki...» [10, c. 225]. Фактично голова держави тільки дихав і міг поворухнути пальцями, 
перебуваючи в спеціально знезараженому приміщенні, під'єднаний до крапельниць та інших приладів, що перевіряють стан життєдіяльності $[10$, c.206].

Уже в імені криється винятковість керівника, з чим пов'язаний слот якість. Монодікос не такий, як усі, ідеальний, святий; Ілон вклоняється навіть мап-тілу, на якому тренується робити масаж, вважає, що займенник він, коли йдеться про керівника, треба писати з великої літери. У Монодікоса кров інша, більше насичена киснем і має лікувальні властивості [10, с. 220-221].

Надзвичайно актуальним є слот причина появи диктатора. Монодікос з'явився в часи катастроф i воєн, тому люди сприйняли його як визволителя. „Przyszedl, gdy wszyscy najbardziej go potrzebowali, gdy katastrofa z plastikiem zniszczyla nie tylko domy, fabryki i szpitale... Dzieta zniszczenia dopetniła wojna. Kiedy spadały satelity, wygladały jak pociski, jak noże wymierzone $w$ Ziemię» [10, c.212]. Подібні причини появи диктатора $\epsilon$ прототиповими, спостерігаються в численних дослідженнях виникнення тоталітарних режимів у XX ст. Аналогічно письменник А. Кузнецов у романі «Бабин Яр» пояснює механізм формування тоталітарної влади: «Світ поганий. $€$ благодійник з планом перетворення. За цим планом сьогодні потрібні жертви, але на фініші гарантований загальний рай. Кілька запальних слів, куля в потилицю недовірливим - i ось уже мільйонні натовпи охоплені поривом» [6, с. 354]. У ХX ст. основною проблемою була втрата віри, отже, з'являлися диктатори, які «були в якомусь сенсі гуманістами. Вони відчували себе рятівниками якщо не всього людства, то принаймні власної нації. Адже якщо рай втрачено на небі, я побудую його на землі. ...ідеї Ніцше зняли 3 самопроголошених месій моральну відповідальність: почавши з благих намірів, вони вже наступного дня прокидалися кровожерами» [5].

Місцем дії в оповіданні виступає весь світ, планета Земля; Монодікос уособлює єдине світове правління. У зазначеному часі простежується елемент фантастики, адже жодна людина не може жити й бути при владі 312 років. Слот об'єкm містить інформацію про народ, яким керує диктатор. Люди звикли до усталеного порядку, змирилися з недоліками й бояться втратити Монодікоса, бо він у їхній свідомості уособлює мир і лад, без нього настане хаос.

Слот об'єкт тісно пов'язаний зі слотом оцінка, бо завдяки ставленню народу формується постать диктатора. Існує навіть думка, що «народ повноправний співучасник диктатури, а зовсім не ії жертва» [5]. У творі люди за ставленням до свого керівника розділилися на три групи: перші його обожнюють, щиро, як головний герой Ілон, чи удавано, як деякі 
рекони (співкерівники); другі нейтрально ставляться до всього, пов'язаного з Монодікосом: це для них лише традиція, яку необхідно підтримувати задля ладу на Землі; третю малочисельну групу становлять бунтівники, що прагнуть змінити світ, не ототожнюють Монодікоса 3 гармонією й миром, вважають, що слід дати нещасному старому померти. 3 бунтівниками потоваришувала донька Ілона, через що посварилася з батьком і пішла з дому.

Як у багатьох країнах 3 тоталітарним режимом влада робить враження демократії: маніфестанти мають право вже багато років стояти біля мосту з заклеєними ротами [10, с. 202] і раз на рік Монодікоса в спеціальному візку з численною охороною й лікарями вивозять у місто, а люди мають дозвіл написати на футболках про своє незадоволення й пройти перед очами процесії [10, с. 229].

У суспільстві встановлено певний лад, побудований на щорічному повторюванні свят, подій, пов'язаних з циклами життя Монодікоса. Завжди в один і той самий день він помирав на 40 годин, це був найсуворіший траур для народу, потім оживав у прямому ефірі всіх 3MI, про що дізнавалися через порух пальців - наставало свято. Але після воскресіння доводилося довго лікувати Нашого Брата, його одужання теж відзначалося [10, с. 235-239]. Повторювані дії нагадують магічні, вони заспокоюють, притупляють свідомість, вселяють відчуття псевдоладу. Ця інформація міститься у слоті спосіб керування.

Отже, можна простежити, що, хоча оповідання «Календар людських свят» i названо дивацьким, структура фрейму диктатор цілком реалістична, включає слоти суб'єкт, кількість, якість, причина появи, місце, час, об'єкт, оцінка, дія, спосіб дї. Аналогічні особливості спостерігаються не лише в художній, але й в реальній картині світу.

\section{Література:}

1. Борисов А.А. Механизмы формирования текстовой когерентности (фреймовый подход). Современные проблемы науки и образования. 2014. № 3. URL: http://www.science-education.ru/ru/article/view?id=12811

2. Бушуева Л.А. Реализация инвариантной модели фрейма поступка (на примере фрейма «чудачество»). Вестник Волжского университета имени В.Н.Татищева. 2017. № 2. T.1. URL: https://cyberleninka.ru/article/n/ realizatsiya-invariantnoy-modeli-freyma-postupka-na-primere-freymachudachestvo/viewer

3. Жаботинская С.А. Концептуальный анализ: типы фреймов. Когнитивная семантика. Материаль второй международной школы- 
семинара по когнитивной лингвистике. Тамбов: Изд-во ТГУ, 2000. Ч. 2. C. $10-13$.

4. Кобозева И.М. Лингвистическая семантика. М.: Едиториал УРСС, 2004. $352 \mathrm{c}$.

5. Пульсон К. Герои и антигерои финалиста "Большой книги" Вячеслава Ставецкого. URL: Российская газета - Федеральный выпуск № 261(8019)

6. Русская литература XX века. Прозаики, поэты, драматурги: библиографический словарь: в 3 т. / под ред. Н.Н.Скатова. М.: ОЛМАПРЕСС Инвест, 2005. Т. 2. 720 с.

7. Словник української мови: в 11 томах/ за ред. І. К. Білодіда. К.: Наукова думка, 1971. Т. 2. 550 с.

8. Шнякина Н.Ю. Фреймовый анализ в сфере изучения ситуативного знания (на материале немецкого языка). Вестник Челябинского государственного университета. 2019. № 6 (428). Филологические науки. Вып. 117. С. 210-218.

9. Słownik języka polskiego PWN. URL: https://sjp.pwn.pl/slowniki/ dyktator.html

10. Tokarczuk O. Opowiadania bizarne. Krarów: Wydawnictwo literackie, 2019. $256 \mathrm{~s}$.

11. Wielki słownik języka polskiego. URL: https://www.wsjp.pl/ do_druku.php?id_hasla=25570\&id_znaczenia=0 